\title{
THE NARRATIVE OF ADRASTUS IN STATIUS' THEBAID AS A CASE STUDY OF INTRATEXTUAL POETICS
}

\begin{abstract}
Summary: The embedded narrative of Adrastus (Stat. Theb. 1. 577-668) is full of verbal repetition and is echoed in later parts of the epic, especially the Nemean episode (Theb. 4-6). This paper investigates these intratextual parallels and tries to pin down the effects of these echoes. The verbal repetition highlights motifs that play an important role in the Thebaid as a whole and connects characters, events, motifs and episodes. This intratextuality sometimes creates unity, sometimes - contrarily - discontinuity or ambiguity. This article is a case study of Statius' intratextual poetics, a field that has thus far received little attention in scholarship on the Thebaid.
\end{abstract}

Key words: Statius, Thebaid, intratextuality, verbal repetition, allusion, Adrastus, Apollo, Hypsipyle

Is it possible that an embedded narrative with its own storyline contributes to the unity of the Thebaid? And if so, what kind of unity? Or does it rather signify the discontinuity that many have seen in this epic? The aetiological narrative of Adrastus at the end of Thebaid book 1 (in scholarship often referred to as the 'Linus and Coroebus story') has featured in many discussions on this topic. This article focuses on the high degree of verbal repetition within the narrative and echoes of the narrative in later parts of the Thebaid. ${ }^{1}$ The intratextual repetition functions as an allusive device, drawing the reader's attention to the similarity or dissimilarity of characters and events in the embedded narrative. At the same time, it highlights themes that are important both in that narrative itself and in the rest of the epic. ${ }^{2}$

${ }^{1}$ This paper is the result of oral presentations held at the Dutch Latinists Day at the Radboud University (Nijmegen, January 2014) and the Flavian Epic Network Conference on Unity and Inconsistency at the Eötvös Loránd University (Budapest, September 2014). I would like to thank the participants for the useful discussions and suggestions. Mark Heerink and Irene de Jong have given valuable advice on the written version.

${ }^{2}$ For the allusiveness of repetition, see WILls, J.: Repetition in Latin Poetry: Figures of Allusion. Oxford 1996, esp. 18-24 and 30-31. For intertextual and intratextual correspondences in the Thebaid, 
Early Statian scholarship saw the narrative of Adrastus chiefly as a meaningless interruption of the primary narrative - a good example of the alleged mediocre poetical abilities of Statius. ${ }^{3}$ Since publications by Vessey on this narrative, that attitude has changed. ${ }^{4} \mathrm{He}$ argued that the narrative thematizes the opposition between pietas and impietas and in this way foreshadows events that happen later on in the epic. Since then, many have seen the episode as a mirror of the primary narrative, but have argued in different directions. ${ }^{5}$ Others have drawn attention to the intertextuality of the narrative, mainly discussing the relation to the Vergilian embedded narrative of Hercules and Cacus, told by King Evander to Aeneas in Aeneid 8, with which it shares both its setting and parts of its content. Ganiban and most recently, Walter, have argued that these allusions suggest that the narrative in the Thebaid should be read as a subversion of the more positive story in the Aeneid. ${ }^{6}$ McNelis has discussed the Callimachean influences that can be discerned in the story, in his eyes reflecting Statius' poetical programme. ${ }^{7}$ Whatever the individual focus or conclusions, it has become clear that the narrative of Adrastus has a wider significance and functions as a mirrortext for motifs, characters, events and poetics in the rest of the Thebaid. ${ }^{8}$

My contribution continues this line of interpretation, but focuses on the narrative's intratextuality, an approach that has not received much critical attention so far in discussions of this narrative (or the rest of the Thebaid). ${ }^{9}$ In the first part I will investigate mirroring in the narrative itself, while the second part discusses the intratextuality between this narrative and the Nemean episode in Thebaid 4-6.

TAISNE, A. M.: L'esthétique de Stace. Paris 1994, esp. 238-247 on the embedded narratives of Adrastus and Hypsipyle.

${ }_{3}$ E.g. Legras, L.: Étude sur la Thébaïde de Stace, Paris 1905 and ARICò, G.: Sul mito di Lino e Corebo in Stat. Theb. 1.557-668. RFIC 88 (1960) 277-285, esp. 277.

${ }^{4}$ Vessey, D. W. T. C.: Statius and the Thebaid. Cambridge 1973. See also VesSEY, D. W. T. C.: The Significance of the Myth of Linus and Coroebus in Statius' Thebaid I 557-662. AJPh 91 (1970) 315-331.

${ }^{5}$ Most commentators have interpreted the content of the story as disturbing and negative, cf. DOMINIK, W. J.: The Mythic Voice of Statius. Power and Politics in the Thebaid. Leiden, 1994 and NewLANDS, C.: Statius' Programmatic Apollo and the Ending of Book 1 of the Thebaid. In ATHANASSAKI, L. Martin, R. P. - Miller, J. F. (eds.): Apolline Politics and Poetics. Athens 2009, 353-378. Others have read the denouement more positively, e.g. HILL, D.E.: Statius' Thebaid: a Glimmer of Light in a Sea of Darkness. Ramus 18 (1989) 98-118.

${ }^{6}$ GANIBAN, R. T.: Statius and Virgil. The Thebaid and the Reinterpretation of the Aeneid. Cambridge 2007, 9-23 and WALTER, A.: Der Mythos von Linus und Coroebus in Statius' Thebais - ein aitologischer Gegenentwurf zur Aeneis. In Kramer, N. - ReITZ, C. (eds.): Tradition und Erneuung: mediale Strategien in der Zeit der Flavier. Berlin - New York 2010, 63-91.

${ }^{7}$ MCNelis, C.: Statius' Thebaid and the Poetics of Civil War. Cambridge 2007, 25-49. Cf. also Newlands (n. 5). J.-M. Hulls ('Well Stored with Subtle Wiles'. Pyrene, Psamathe and the Flavian Art of Interaction. In MANuwALD, G. - VoIGT, A. [eds.]: Flavian Epic Interactions. Berlin 2013, 343-360) explores the intertextuality between the Statian narrative and the story of Pyrne in Silius Italicus' Punica.

${ }^{8}$ For the concept of a mirror-text or mise en abyme, see DÄLLENBACH, L.: Le récit spéculaire: contribution à l'étude de la mise en abyme. Paris 1977 and BAL, M.: Narratology: Introduction to the Theory of Narrative. Toronto $2009^{3}$.

${ }^{9}$ Intratextuality is actually an underestimated field of research in Latin literature, compared with intertextuality. One of the few attempts to define intratextuality is SHARROCK, A - MORALES, H. (eds.): Intratextuality. Greek and Roman Textual Relations. Oxford 2000. For intertextuality, see especially HINDS, S.: Allusion and Intertext. Dynamics of Appropriation in Roman Poetry. Cambridge 1998. 
The narrative of King Adrastus is told shortly after the exiled Polynices and Tydeus have arrived in Argos, during a festival in honour of Apollo. The king wants to inform his guests about the origins of the festival. In the next hundred lines, the characters and events follow each other at a considerable pace. ${ }^{10}$ After Apollo defeats the serpent Python near Delphi, he goes to King Crotopus of Argos to expiate himself. There, Apollo falls in love with the king's daughter (nameless in the Thebaid, but called Psamathe by Callimachus) and impregnates the girl. She keeps her pregnancy secret in fear of her father's reaction and gives birth to a son (Linus according to other sources, but unnamed in Statius), whom she entrusts to a herdsman to be raised. In an unguarded moment, wild dogs devour the infant. The princess cannot conceal her emotions, goes to Crotopus and confesses what has happened, after which the angry king kills his daughter.

Apollo then creates a monster to revenge the death of both his son and his beloved princess, and sends it to Argos, where it roams through bedrooms devouring infants. The young hero Coroebus cannot bear this disaster to continue, confronts the monster with his fellow-soldiers and finally kills it.

Again Apollo is angered. This time he sends a plague to Argos and demands Coroebus' life as a retribution for his monster's demise. Coroebus goes to the god's newly erected sanctuary in Delphi and confronts him with his actions. The Argive hero declares he is willing to offer his life to save his hometown from the god's wrath. Suddenly, Apollo is moved by the words of Coroebus; he spares his life and ends the plague. From that moment onwards, Adrastus explains, the Argives celebrate this festival to remember the god's clemency.

\section{VERBAL REPETITION IN ADRASTUS' NARRATIVE}

In this section, I will show how verbal repetition in the narrative creates a mirroring effect between characters and events and how these intratextual allusions can be interpreted.

\subsection{Chain of misery}

We start with the destructive forces in the narrative. The dogs that tear the infant Linus apart, for example, can be seen as a prefiguration of Apollo's child-eating monster, as is underlined by verbal parallels. The death of Linus is described as follows:

\section{dira canum rabies morsu depasta cruento disicit.}

$(\text { Theb. 1. 589-590) })^{11}$

\footnotetext{
${ }^{10}$ Paradoxically, the embedded narrative has often been considered a pause of the main narrative. See e.g. Hulls (n. 7) 355, claiming that the narrative has 'a strong digressive feel' and is 'the first in a long series of delays'.

${ }^{11}$ All quotations of Latin are from Statius' Thebaid unless otherwise indicated. The text is that of HILL, D. E.: P. Papini Stati Thebaidos Libri XII. Leiden $1996^{2}$. I have marked verbal repetition in bold.
} 
The ominous rage of dogs, feeding with bloody bites, tears him apart. ${ }^{12}$

The monster sent by Apollo is described in similar words only ten lines below:

haec tum dira lues nocturno squalida passu

illabi thalamis, animasque stirpe recentes

abripere altricum gremiis morsuque cruento

devesci et multum patrio pinguescere luctu.

This ominous pest slides with nocturnal pace squalidly into bedrooms and tears lives newly-born from their wet-nurses' breasts, devours them with bloody bites and grows fat on paternal mourning. ${ }^{13}$

Both the dogs and the monster are labelled dirus and both feed themselves with lethal 'bloody bites'. Later on, Apollo's monster is described as cruento / ... monstro (1. 636-637). Their victims are similar, too. The dogs kill the infant Linus, while Apollo's monster tears new-borns from their nurses' breasts (1. 602-603).

When Coroebus has killed the monster, wild animals, such as birds and dogs, do not eat its corpse. On the contrary, they flee from it or merely gape at it in fear:

impastae fugistis aues, rabidamque canum uim

oraque sicca ferunt trepidorum inhiasse luporum.

Unfed do you, birds, flee away and they say the raging violence of dogs and mouths of trembling wolves gaped.

The words rabidamque canum uim recall the dogs that devoured Linus in line 589 (dira canum rabies). ${ }^{14}$ But this time they are outclassed in dreadfulness by the monster that Apollo has sent forth from the underworld and they do not dare to feed on its corpse. $^{15}$

The monster, in its turn, is a foreshadowing of Apollo's second punishment of Argos - the plague. The monster is actually called lues, 'pest' (1.601), and she slides through Argive bedrooms nocturno squalida passu (1. 601) 'filthy with nocturnal pace'. When the Argives gaze at her dead body, it is described as crasso squalentia pectora tabo (1.618), 'the breasts filthy with thick pestilence'.

${ }^{12}$ Translations are usually my own, and sometimes adapted with many changes from SHACKLETON BAILEY, D. R.: Statius Thebaid Books 1-7. Cambridge, Mass. - London 2003.

${ }^{13}$ SHACKLETON BAILEY (n. 12) translates patrio luctu as 'the land's mourning', what might also lurk behind patrius, but I would rather interpret the adjective as reflecting the mourning of fathers, bereaved of their children.

${ }^{14}$ The phrase also reminds of Lucretius' description of the pest in 6. 1222. Dogs are victims of the plague and described as fida canum vis 'the loyal strength of dogs'. Statius inverts the situation by making the dogs the culprits (dira) and spectators of a 'plague' (the monster was described as lues in 1. 601) instead of victims. Perhaps the word ferunt is a metapoetical marker of this intertextual allusion. For such 'Alexandrian footnotes' see HINDS (n. 9) 1-5.

${ }^{15}$ The phrasing is quite vague, but inhiasse together with trepidorum seems to mean that they gape at the monster in fear. Barth (quoted by Heuvel, H.: Publii Papinii Statii Thebaidos liber primus, versione Batava commentarioque exegetico instructus. Zutphen 1932, 258f.) thinks that they are repelled by the terrible smell the monster's corpse exhales. 
The words squalo and tabum reappear in Coroebus' description of the plague in Apollo's temple - just after he has recalled his killing of the monster:

ego sum qui caede subegi,

Phoebe, tuum mortale nefas, quem nubibus atris

et squalente die, nigra quem tabe sinistri

quaeris, inique, poli.

I am the person who subdued in death, Phoebus, your mortal evil, he whom you, unjust one, seek with black clouds and filthy daylight, with the black pestilence of an unfavourable heaven.

The plague's victims are described in line 632 as dulces animae, echoing the victims of the monster, who are torn away from their wet-nurses: animasque ... recentes (1. 602). ${ }^{16}$ The black clouds that accompany the Apolline plague (nubibus atris, 1. 646) may recall the orbibus atris (563) of the Python. Note the identical metrical sedes of both phrases at the end of the hexameter and the fact that both lines contain a reference to Apollo (deus Phoebe).

The verbal repetition enforces the connection between the successive manifestations of monsters and monstrous events. Evil repeats itself, although it evolves into something direr than it was before. The Python is a terrifying monster, but no victims are mentioned. The dogs devour an innocent boy. The monster that is deliberately created by Apollo causes a massacre among Argive children. And the plague finally causes destruction among the total population. The connection between these events seems to be highlighted by the use of the adjective dirus for both the dogs and Apollo's monster. The word originates from the religious vocabulary of divination, meaning 'ill-boding, ominous'. ${ }^{17}$ That is exactly what the dogs and the monster are. They predict worse evil to come.

This motif of increasing evil and consequent misery has wider significance than for the narrative of Adrastus alone. In the primary narrative of the Thebaid we can discern a similar continuation and increase of misery, brought about by gods allowing dark powers to exact their power, culminating in the fratricide of Eteocles and Polynices. The dire events in Adrastus' tale are a foreboding of terrible things to come. ${ }^{18}$

\subsection{Contrasting pietas and nefas}

Coroebus, the hero of the narrative, who frees Argos of both the monster and the plague, is the antipode of Apollo, who has caused these disasters. The antithesis between the

\footnotetext{
${ }^{16}$ The phrase is an allusion to Aeneas' description of the plague (lues) at Crete: linquebant dulcis animas (Verg. A. 3. 140) 'they [sc. Aeneas' men] left their sweet lives'. HEUVEL (n. 15) 259f. notes the bold grammatical innovation of Statius, making dulces animae subject.

${ }^{17}$ TLL 5.1.1268.67 s.v.

${ }^{18}$ Not only for the Argives, as MCNELIS (n. 7) 37 notes, but also for Thebes, 'which is also subject to recurring violence'. See also WALTER (n. 6) 77.
} 
antagonists becomes clear from their deeds. Coroebus defeats the monster that Apollo sent to Argos and confronts the god with his unjust behaviour in his newly erected shrine at Delphi.

This contrast is underlined on a verbal level as well. A good example is furnished by their weapons. Apollo's sending of the plague is described as follows:

\section{summaque biuerticis umbra \\ Parnassi residens arcu crudelis iniquo pestifera arma iacit}

Sitting in the highest shadow of double-peaked Parnassus the cruel one discharges from his unjust bow the pest-bearing arms.

The god is called 'cruel' and is shooting 'pest-bearing' arrows from his 'unjust bow'. Nine lines below, the narrator addresses Coroebus in contrasting vocabulary:

fortunate animi longumque in saecula digne
promeriture diem! non tu pia degener arma
occulis aut certae trepidas occurrere morti.

You are fortunate because of your courage and rightly deserve a long life through the ages! You, who are not degenerate, do not hide your pious arms or fear to meet a certain death.

Note that Coroebus' weapons are called 'pious' and that he is 'not degenerate' - while Apollo is in fact a degenerate god who punishes the city where he was expiated. Another salient detail is the place where the confrontation between Coroebus and Apollo takes place - Cirrhaei in limine templi (1.641) 'on the threshold of Cirrha's temple'. This is the newly erected sanctuary of Apollo near Delphi, where Apollo killed the Python, as was narrated by Adrastus at the beginning of the episode - Cirrhaeique ... centum per iugera campi (1.568) 'over a hundred acres of Cirrha's plain'. The repetition of the same geographical adjective seems to stress the subversive role Apollo plays. At first he seems to be a saviour, who frees the world of a terrible monster like Hercules did. Not very long thereafter, however, he creates his own monster and sends a plague. It is Coroebus who reminds the god of this degeneration in exactly the place where he performed his last just deed. The hero addresses the Delphic god with the vocative inique (1.648) 'unjust one', picking up the words of the narrator, who described the god's bow as arcu ... iniquo (1. 629).

Coroebus on the other hand has defeated Apollo's monster and continues rescuing his city from evil. This hero can be seen as a symbol of virtus and pietas. The narrator Adrastus called his weapons 'pious' while praising him, and the hero thinks highly of himself as well: mea me pietas et conscia uirtus / has egere uias (1. 644$645)$ 'my loyalty and conscious virtue have brought me along these ways'. Nevertheless, he gets a meagre reward for his toils at the end of the story. Apollo grants him his life, but this is called a tristemque ... honorem (663) 'a sad honour'. It is Apollo who receives the greatest honour, for it is the god's clemency towards their city that the Argives commemorate with an annual festival. This is stressed by the repetition 
of the word honos at the beginning and the end of Adrastus' narrative (honorem 1. 558 and honos 1. 668), both referring to the festival. No matter how noble Coroebus' acts were and how subversive the god's, Apollo is the champion. ${ }^{19}$

The confrontation between Apollo and Coroebus brings us back to king Crotopus and his daughter at the beginning of the narrative. Coroebus' confrontation with the god seems to echo Psamathe's reaction when she hears about the death of her son Linus.

ipsa ultro saeuis plangoribus amens

tecta replet, uacuumque ferens uelamine pectus

occurit confessa patri; nec motus et atro

imperat (infandum!) cupientem occumbere leto.

On her side she fills the palace in her rage with fierce laments and with her breast free of garment, she runs to her father to confess. He is not moved and orders (an unspeakable act!) that she meets black death as she desires.

The girl's attitude towards her father foreshadows the way the angered Coroebus confronts Apollo. He likewise runs towards his destruction (non ... aut certae trepidas occurere morti, 1. 640) and is willing to give up his life: insignemque animam leto demitte (1.659) 'send my remarkable life down to death'.

The girl and Coroebus are the only persons in the narrative that are explicitly associated with pietas. As we saw earlier, Coroebus' weapons are pia (1.639) and he mentions his own pietas in 1. 644. Psamathe is described as follows:

\section{mira decore pio servabat nata penates}

Marvellous in her pious grace his daughter took care of the household gods

This verbal repetition stresses the similarity between Psamathe and Coroebus. Both pious and innocent mortals run into a situation from which the only escape seems to be death. A great difference is, of course, that Crotopus orders his daughter to be killed right away, whereas Apollo, in the end, grants Coroebus his life.

Coroebus' opponent Apollo, on the other hand, recalls his former host Crotopus. Their actions are both labelled 'unspeakable'. The narrator comments on Crotopus ordering his daughter's death with the interjection infandum! (1. 595). Two lines below, we are told that Apollo creates a monster in infandis ... / Eumenidum thalamis (1. 597) 'in the unspeakable bedrooms of the Furies'. Crotopus' deed is cruel, but the reaction of Apollo - creating a monster - is in no way inferior to that cruelty.

${ }^{19}$ On the subversive nature of Statius' Apollo in the Thebaid, see DOMINIK (n. 5) 63-70, NEWLANDS (n. 5) and WALTER (n. 6) 76-80. Apollo criticises his own actions in 9. 657: saeuus ego immeritusque coli 'cruel and unworthy of worship', saeuus perhaps being an echo of saeuior ... / Delius insurgit (1. 627-628) 'the god rose fiercer'. 


\subsection{Ambiguous similarities}

In the preceding section, I have discussed instances of verbal repetition that stress connections that are hardly shocking: the pious Coroebus echoes the pious Psamathe, and Crotopus and Apollo both commit unspeakable acts. But matters are more complicated than this black-and-white picture of good and evil, and it is again verbal repetition that underlines this. ${ }^{20}$

Apollo, to begin with, is not only a culprit, but in a sense also a victim. The emotions he shows bear remarkable similarities to those expressed by the Argives. The monster he creates in Tartarus is meant to give him consolation for the grief or anger he feels for the loss of his girl: maestae solacia morti (1.596) 'a solace for the sad death' ${ }^{21}$ When this monster is subsequently killed by Coroebus his anger grows: saeuior ... / Delius insurgit (627-628) 'the Delian god rose fiercer'. It increases even more when Coroebus dares to teach the god a lesson in his own sanctuary: sacras ita vocibus asperat iras (1.642) 'so because of his [i.e. Coroebus'] words he sharpens his sacred ire'. Apollo's last emotion is surprise, when he grants Coroebus his life.

\section{at tu, stupefacti a limine Phoebi \\ exoneratus abis \\ (1. 665-666) \\ but you [Coroebus], go away from the threshold of the stupefied Phoebus, free of burden}

The emotions felt by Apollo - anger, the need for consolation, increased anger and surprise - are experienced by the Argives, too, when they gaze at the corpse of Apollo's monster, after it has been slaughtered by Coroebus:

\section{stupet Inacha pubes \\ magnaque post lacrimas etiamnum gaudia pallent. \\ hi trabibus duris (solacia uana dolori) \\ proterere exanimos artus asprosque molares \\ deculcare genis; nequit iram explere potestas.}

The Inachian youth is stupefied and after their tears they are still pale in their great joy. Some crush the lifeless limbs with hard stakes (an idle solace for their grief) and trample sharp rocks upon her cheeks; their power could not satisfy their wrath.

They are amazed (stupet Inacha pubes 1. 619) and start to mutilate the corpse. This mutilation is supposed to give them comfort, but in vain: solacia uana dolori (1. 621). They are not able to release their anger: nequit iram explere potestas (1.623). The emotions are the same, although they appear in reversed order.

\footnotetext{
${ }^{20}$ For the instability of categories like good and evil in the Thebaid see DOMINIK (n. 5) 29-33 and WALTER (n. 6) 71.

${ }^{21}$ It is not made explicit whose death actually moves Apollo; morti is singular and the preceding line mentions Crotopus' orders to kill Psamathe, but it could also refer to Linus' death or both. See GANIBAN (n. 6) 9, n. 47.
} 
Who is victim, who is culprit? The Argives are victims of Apollo's anger, but they are perhaps not free from guilt either. It was their king who killed his daughter and their hero, Coroebus, who killed Apollo's monster, which turns him paradoxically into an Apollo, killing the monstrous Python. ${ }^{22}$ I think the verbal repetitions encourage the reader to question the legitimacy of both acts. Killing monsters is a highly ambiguous act. The line between good and evil becomes somewhat blurred by this association, as is the case in other parts of the Thebaid as well. ${ }^{23}$

A last repetition that I want to examine is centred on the word thalamus, meaning 'inner room, marriage-chamber' and metonymically also 'marriage, union'. ${ }^{24}$ Within 21 lines this word appears four times. The first two attestations occur in the description of the encounter between Psamathe and Apollo; the other two in the description of Apollo's monster.

When the narrator describes the girl's anxiety to confess the secret of her child to her father, he comments:

neque enim ille coactis

donasset thalamis ueniam pater

for her father would not have forgiven even a forced union ${ }^{25}$

When Crotopus has killed Psamathe, Apollo is said to be sero memor thalami (1. 596) 'remembering his union too late'. Two lines below, still in the same sentence, the word reappears. Now it denotes the place where the avenging monster is conceived:

\section{Phoebe, paras monstrum infandis Acheronte sub imo conceptum Eumenidum thalamis cui uirginis ora pectoraque.}

Phoebus, you create a monster, conceived in unspeakable chambers of the furies at the bottom of the Acheron, that has the face and breasts of a virgin.

Somewhat later, this same monster slides through Argive bedrooms looking for young children: nocturno squalida passu / illabi thalamis (1.601-602) 'with nocturnal pace [it] slides squalidly into chambers'.

${ }^{22}$ I owe this suggestion to Mark Heerink.

${ }^{23}$ See e.g. MCNELIS (n. 7) 37. One can think of the role of gods in other parts of the epic, such as Apollo's actions in aiding Amphiaraus in book 6 and 7, but also of a hero like Theseus, who attacks Thebes and slaughters Creon before restoring piety and clemency in the epic's last book.

${ }^{24}$ For the use of thalamus see ZISSOS, A.: Valerius Flaccus' Argonautica Book 1. Edited with Introduction, Translation and Commentary. Oxford 2008, 130-131. These lines in Valerius Flaccus refer to the forced marriage (insperatos ... thalamos) of Thetis with Peleus, which resembles the forced union of Psamathe with Apollo (coactis ... thalamis, 1. 578-579), on which see below.

${ }^{25}$ Usually, the union between Apollo and the girl is interpreted as a rape, mainly because of the phrases passa deum (1.575) 'having suffered the god' and coactis ... thalamis 'forced union' in the lines under discussion. So e.g. DominiK (n. 5) 66 and Newlands (n. 5) 358. Hulls (n. 7) 348 and 353, however, argues that Statius' language is ambiguous and does not necessarily point into the direction of a rape, but see my remarks on the parallels with Hypsipyle's union with Jason below. See for further references Soerink, J.: The Beginning of Doom. Statius Thebaid 5.499-753. Introduction, Text, Commentary. Diss. Groningen 2014, 213f. (available on http://irs.ub.rug.nl/ppn/383480167). 
The repetition of this word does not seem to be coincidental. It establishes a link between the thalamus of Apollo and Psamathe on the one hand and the revenge for the girl's death on the other. The avenging monster is conceived in thalami and performs its task sliding through Argive thalami. The girl and the monster also show physical similarities, as we can deduce from the description of the creature: cui uirginis ora / pectoraque (1. 598-599). ${ }^{26}$ The enjambment of pectoraque highlights the body part which so prominently played a role in the girl's confession, emphatically showing her breasts, with which she has fed her baby, to her father: uacuumque ferens uelamine pectus (1.594).

The suggestion is made that the monster is in some way not really separate from the girl she avenges. Fontenrose, who gives a reconstruction of the origins of the myth, ${ }^{27}$ has already pointed at mythological similarities between the monster, called Poine according to other sources, ${ }^{28}$ and Psamathe: "[Poine], Argive Psamathe's avenging spirit, is Psamathe herself'. ${ }^{29}$ The same motif is discernable in the myth of the Libyan Queen Lamia, who had lost her own child, transformed into a monster and "raided the land snatching babes from their mothers and devouring them". 30 Statius has picked up this mythological motif of a bereaved mother turning into a demon in his narrative, as is stressed by the repetition of the word thalamus. Apollo's creature is the monstrous version of Psamathe, who punishes Argos for what has been done to her. Again, the line between victim and culprit is blurred.

The examples discussed above show that the narrative of Adrastus is not only structured chronologically, but that verbal repetitions also forge a complicated web of interactions between events and characters, the effect of which varies. The parallels between the Python, the dogs that devour Linus, the monster and the plague stress the correlative continuation and increase of evil. Other repetitions highlight the similarity between characters in this story, such as Crotopus' daughter and Coroebus - who are both associated with pietas - and Crotopus and Apollo with the opposite.

The verbal repetition also draws the reader's attention to more complicated associations, such as the monster's similarity with the king's daughter. Should the reader interpret the monster as a reincarnation of the Argive princess? Does that make the monster's actions more justified? And what about Apollo? He seems to be a perverted version of the Vergilian Apollo. But on the other hand he shows emotions that are comparable with those of the Argives. Do these emotions make him more human? This human side of the god is most apparent when he forgives Coroebus and grants him his life - at his own surprise. ${ }^{31}$ His mercy for Argos and Coroebus makes him perhaps less cruel. While the cruelty of Crotopus, the killing of the monster by

\footnotetext{
${ }^{26}$ See Hulls (n. 7) 359, suggesting that "Apollo's monster symbolizes the subjugation of feminine figures by aggressively masculine dynamics".

${ }^{27}$ Fontenrose, J.: Python. A Study of Delphic Myth and Its Origins. Berkeley - Los Angeles 1959, 104-120.

${ }^{28}$ Paus. 1. 43.7 and 2. 19. 7; Conon 19.

${ }^{29}$ FONTENROSE (n. 27) 113.

${ }^{30}$ FonTEnRose (n. 27) 114. "The Apollo-Psamathe story was either derived from or fitted to a story of the seductive Lamia."

${ }^{31}$ For this human side of Apollo see WALTER (n. 6) 72 and MCNELIS (n. 7) 45.
} 
Coroebus and the insatiable anger of the Argives make them, however, not altogether innocent. The (secondary) narrator Adrastus does not seem to notice these ambiguities as he tells his tale. ${ }^{32}$

\section{VERBAL REPETITION IN THE NEMEAN BOOKS}

Verbal repetition proves to be an important intratextual device in the rest of the epic as well. The mirroring within the narrative of Adrastus invites the reader to look at this episode as a mirror for the primary narrative of the Thebaid. In this second section of my paper, I will discuss examples of such mirroring between this narrative and the Nemean books 4, 5 and 6, a part of the Thebaid that has been equally critiqued for its alleged redundancy.

A striking similarity is the appearance of another embedded narrative. Hypsipyle, the former queen of Lemnos, tells in about 450 lines the story of the Lemnian women. They decide, in their frenzy, to kill all men on the island. Hypsipyle saves her father, king Thoas, by letting him escape over sea in a chest. When Jason and his Argonauts later arrive, this results at first instance in a fight. After a cease-fire, the visitors are welcomed by the Lemnians, who are longing for men after a long period of abstinence. Jason falls in love with Queen Hypsipyle and they have two children. The Argonauts then have to leave to continue their journey to Colchis. The parallels with Jason and Medea on the one hand and Dido and Aeneas on the other are obvious. Then, the Lemnian women find out that Hypsipyle did not participate in the parricide and therefore decide to banish the queen. Hypsipyle finds a place of shelter in the palace of Lygurgus and Eurydice, the royal couple of Nemea, and becomes the nurse of their son Opheltes.

The appearance of yet another frame narrative is not the only correspondence with Thebaid 1 . When one looks closer, the Nemean episode contains many allusions to the narrative of Adrastus, some of which have been discussed in previous scholarship. ${ }^{33}$ In my discussion I will add intratextual allusions that have been overlooked so far, so as to give a full sense of the mirroring between the two episodes.

\subsection{The Nemean drought and the Argive plague}

The context of the Nemean episode is the drought, initiated by Bacchus to stop the army of the Seven from destroying his favoured city of Thebes. The god orders the nymphs to assist him in stopping the Argive host, addressing them as follows:

${ }^{32}$ For Adrastus as an 'ignorant narrator' see MCNELIS (n. 7) 40-44 and NEWLANDS (n. 5) 367.

${ }^{33}$ E.g. VeSSEY, D. W. T. C.: Notes on the Hypsipyle episode in Statius Thebaid 4-6. BICS 17 (1970) 44-54, CAVIGLIA, F.: La Thebaide - Libro I. Introduzione, testo, traduzione e note. Roma 1973, and MCNELIS (n. 7). 
uim coeptis indulgent astra, meaeque

aestifer Erigones spumat canis

(4. 691-692)

The stars yield power to my undertaking and the heat-bearing dog of my Erigone foams

These lines recall the plague that Apollo sent to Argos in book 1. The dog star that is referred to (meaeque aestifer Erigones ... canis, 4. 692) is also mentioned in 1. 635 (Sirius). ${ }^{34}$ Adrastus, unwittingly, ${ }^{35}$ echoes his own narrative some 55 lines later, when Adrastus asks Hypsipyle for assistance in finding water for the Argive troops, referring to the drought:

diua potens nemorum (nam te uultusque pudorque

mortali de stripe negant), quae laeta sub isto

igne poli non quaeris aquas, succurre propinquis gentibus

Goddess, you who have power over the woods (for your face and modesty tell that you are not of mortal stock), you who happily do not seek for water under this fire of heaven, please help neighbouring peoples.

Verbally these words remind us of Crotopus, who asks (quaerenti) for the cause of the plague in his realm:

quaerenti quae causa duci, quis ab aethere laeuus

ignis et in totum regnaret Sirius annum

their leader asks what the causes are, what the unfavourable fire from heaven means and why Sirius reigns all year round

Similar vocabulary is used by Coroebus, accusing Apollo of sending the plague to Argos:

\section{nigra quem tabe sinistri \\ quaeris, inique, poli.}

[I am the person] whom you seek for, unjust one, with the black corruption of an unfavourable heaven.

There is also a reminder of the plague in the suffering of the Argive soldiers, whose faces have become pale because of their thirst (idem omnes pallorque ... habet 4. 774-775 'a pallor has all men alike'). The murky cloud of the plague that hung over Argos in book 1 was called pallidus (1. 660) by Coroebus:

\footnotetext{
${ }^{34}$ The use of canis might perhaps refer to the dogs that devour Linus as well. Remember that these dogs were closely associated with Apollo's plague.

${ }^{35}$ For Adrastus' ignorance in this passage see PARKES, R.: Statius Thebaid 4. Edited with an Introduction, Translation and Commentary. Oxford 2012, 753-760. See also n. 32 above.
} 
sed illum,

pallidus Inachiis qui desuper imminet Argis,

dum morior, dispelle globum.

But while I die, dispel that mass that with its pallor threatens Inachian Argos from above.

The adjective should probably be taken as an enallage, referring to the effect of the plague on people. ${ }^{36}$

One could say that these verbal correspondences do not carry much weight, since both passages describe people suffering from heat. Words like 'fire' and 'pallor' naturally belong to a writer's stock vocabulary for describing such a situation. I argue, however, that the 'thematic' similarity between the drought and the plague actually adds to the significance of the allusions, instead of weakening it. The Argive people are once again victims of a terrible heat, which is the punishment of a god in both cases. The drought of Nemea again brings to the surface the recurring motif of the vindictive god, this time Bacchus. It does not seem a coincidence that Apollo (in his role of the Sun God) plays a supportive role in the wine-god's scheme as the latter declares to the nymphs: adiuuat ipse / Phoebus adhuc summo (4. 689-690) 'Phoebus himself assists from up high'. ${ }^{37}$ The place itself also recalls the narrative of book 1 , as Apollo's encounter with Psamathe - the beginning of all misery in that narrative took place Nemeaei ad fluminis undam (1.575) 'at the water of Nemea's stream'. The Argives will again encounter doom in the ominous Nemean fields, searching for water. $^{38}$

\subsection{Hypsipyle and Opheltes, Psamathe and Linus}

Not only the context of the Nemean episode mirrors the narrative of book 1, but also its characters. Hypsipyle, to start with, recalls Psamathe, which becomes clear as Adrastus, still ignorant of the person he is talking to, addresses her thus:

\section{arquitenens seu te Latonia casto}

de grege transmisit thalamis, seu lapsus ab astris

non humilis fecundat amor (neque enim ipse

deorum arbiter Argolidum thalamis nouus), aspice maesta

agmina.

Whether the bow-bearing daughter of Latona has sent you from her chaste company to a bedchamber or a love of no humble order, descended from the stars, makes you fruitful (for the ruler of the gods himself is no stranger to bedrooms of Argive women), look upon our sad troops.

\footnotetext{
${ }^{36}$ HeUVEL (n. 15) n. 660 seems to point in that direction: "Pallidus: = mortis colorem habens. (...) Nubes (...) sic appellatur, quia mortifera est."

37 The invocation of Apollo by the primary narrator, calling for poetical aid, prepared this reappearance of the god. See PARKES (n. 35) 649-651.

${ }^{38}$ I thank Jörn Soerink for pointing out this correspondence to me.
} 
Adrastus politely suggests that she might be a goddess, a motif that goes back to the meeting of Odysseus and Nausicaä in the Odyssey, or else that she is impregnated by a god. The king states that Jupiter himself is familiar with Argive women, referring implicitly to encounters with Io, Danaë and Alcmene. ${ }^{39}$ Another amorous visit of a god to Argos is of course that of Apollo to Psamathe. The last suggestion, that Hypsipyle bears the child of a god, recalls therefore, especially, Psamathe. The verbal allusion that enforces the connection is the word thalamis, conspicuously repeated within two lines. As we saw above, this word signals an important motif in the narrative of Adrastus in book 1. The words of Adrastus in book 4 mark, therefore, the connection between Psamathe and Linus on the one hand and Hypsipyle and Opheltes on the other.

Hypsipyle's answer to Adrastus affirms this connection:

altricem mandati cernitis orbam

pignoris.

(4. 778-779)

You see the childless wet-nurse of a baby entrusted to me.

The fact that the child is entrusted to her (mandati ... / pignoris) recalls Linus, who is entrusted to a herdsman: montiuago pecoris custodi mandat alendum (1.581) '[she] entrusts [her son] to a mountain-wandering guard of the herd for him to rear'. At the same time Hypsipyle adds that she is bereaved of her own children (orbam), whom she had to leave behind on Lemnos. Although her children may still be alive, she shares the experience of bereavement with Psamathe and the Argive mothers, whose children are taken from the bosom of the wet-nurses by Apollo's monster: abripere altricum gremiis (1.603). Moreover, the adjective orbam ominously foreshadows the loss of her current foster child.

Hypsipyle is willing to show the Argives a river nearby and places the infant Opheltes on the ground. One has to think of the place where Linus was put on the ground. "By her action, Hypsipyle triggers a replay of the fate of Linus, the child who is similarly left on the grass (...) and killed by animals", Parkes argues. ${ }^{40}$ This thematic echo is stressed by several verbal allusions:

miserum uicino caespite alumnum

(sic Parcae uoluere) locat

(4. 786-787)

she [i.e. Hypsiyple] places the hapless child on a turf nearby (so the Parcae ordained)

Linus was likewise placed on a turf (uiridi nam caespite terrae, 1. 587) and in his case, too, the role of the Fates is mentioned (sed Fata nec illum / concessere larem, 1. 586-587) For the time being Opheltes stays alive, but the allusion to Linus in this passage must be an ominous sign for the reader. ${ }^{41}$ The allusion to Linus is reinforced in a more detailed description of the surroundings shortly afterwards:

\footnotetext{
${ }^{39}$ PARKES (n. 35) 4.759f. All stories are to be found in Ovid's Metamorphoses.

${ }^{40}$ PARKES (n. 35) 4.785-789. See also VESSEY (n. 4) 104-105 on the correspondences.

${ }^{41}$ The adjective miserum and the mentioning of the Parcae foreshadow this doom as well.
} 
at puer in gremio uernae telluris et alto

gramine nunc faciles sternit procursibus herbas

in uultum nitens, caram modo lactis egeno

nutricem clangore ciens iterumque renidens

et ternis meditans uerba illuctantia labris

miratur nemorum strepitus aut obuia carpit

aut patulo trahit ore diem nemorique malorum

inscius et uitae multum securus inerrat.

But the boy in the bosom of the spring-time earth and the high grass, now spreads out the grasses that yield to him as he goes forward, leaning on his face. Now he calls for his dear nurse with a cry in want of milk; and again he smiles and practices words that struggle on his tender lips. He wonders at the noises of the forest or plucks at what comes in his way or with open mouth draws in his life and unconscious of the dangers and very secure about his life he wanders in the forest.

These lines clearly echo the location where Linus was put down:

non tibi digna, puer, generis cunabula tanti

gramineos dedit herba toros et uimine querno

texta domus; clausa arbutei sub cortice libri

membra tepent, suadetque leues caua filstula somnos,

et pecori commune solum. sed fata nec illum

concessere larem; uiridi nam caespite terrae

proiectum temere et patulo caelum ore trahentem

(1. 582-588)

As a cradle unworthy of such a high birth, my boy, the herbage provided a grassy bed for you and a home woven with oaken twigs. Enclosed under the shell of arbutus bark his limbs grow warm and a hollow reed urges him to light slumber and he shares the soil with the herd. But even such a home did the fates not permit. For thrown down carelessly on a turf of the green earth he draws in the sky with open mouth ...

The remarkable expression patulo trahit ore diem in 4.799 in particular mirrors the similar phrase in 1. 588: patulo caelum ore trahentem. ${ }^{42}$ The other correspondences are perhaps less marked, but together evoke the idyllic pastoral atmosphere in both passages: gremio $\sim$ cunabula $(1.582)$; telluris $\sim$ terrae $(1.587)$; gramine $\sim$ gramineos (1. 583); herbas $\sim$ herba (1.583). The parallels with Linus foreshadow the imminent

${ }^{42}$ HeUvel (n. 15) and CAViglia (n. 33) both mention this parallel in their commentaries, without further explanation. PARKES (n. 35) translates diem with 'daylight', but dies here rather means 'life' or 'life time' (TLL 5.1.1033.14 s.v. dies), provided by the air he breathes (note that dies is also metaphorically used for caelum, cf. TLL 5.1.1028.51 s.v.). 
destruction of Opheltes, his death being postponed by the frame narrative told by Hypsipyle to the Argives. ${ }^{43}$

The connection between Hypsipyle and Psamathe is established by the similarities between Opheltes and Linus and is strengthened in her description of Jason as a brute who impregnated her.

nec non ipsa tamen, thalami monimenta coacti,
enitor geminos, duroque sub hospite mater
nomen aui renouo

(5. 463-465)

I myself, too, bring forth twins, memorials of a forced bed and under the harsh guest I renew the name of his grandfather. ${ }^{44}$

Her children remind her of her 'forced union' with Jason (coacti ... thalami), which is a clear allusion to the forced union of Psamathe with Apollo (coactis ... thalamis). Both women are victims of male violence and both wish to die, ${ }^{45}$ although Hypsipyle stays alive and is finally reunited with her own sons in 5.710-730. The word monimenta is perhaps an extra marker of this intratextuality. For Hypsipyle the children are the 'memorials' of Jason, but for the reader they are 'memorials' as well, reminding him of Linus, that other child of a forced union.

A huge difference with Psamathe's innocence concerning Linus' death is Hypsipyle's negligence of the child entrusted to her care, and this bears some resemblance with Apollo's forgetfulness of Psamathe and his son. When Hypsipyle's story comes to an end at 5. 498, the narrator states that she has forgotten Opheltes: immemor $a b$ sentis (sic di suasistis) alumni (5.501) 'oblivious (so the gods would have it) of her absent foster child'. This echoes Adrastus' description of Apollo, who remembers Psamathe and his child too late: sero memor thalami (1. 596). Hypsipyle can be held at least partly responsible for Opheltes' death, just like Apollo's obliviousness caused both Linus' and Psamathe's death. ${ }^{46}$

The similarity with Apollo is again hinted at when Hypsipyle emotionally states that Opheltes was for her rerum et patriae solamen ademptae (5.609) 'a solace for my lost possessions and fatherland'. This seems to be a conflation of two phrases referring to Apollo's monster: maestae solacia morti (1. 596) 'a solace for the sad death' and fatis ultricis ademptae (1.627) '[Apollo is angered] because of the fate of his lost revenger'. Hypsipyle is bereaved of the infant that brought her solace just as Apollo is robbed of the monster that was supposed to comfort him. Such allusions question the innocence of Hypsipyle, just as the verbal allusions to Apollo's monster in the narrative of Adrastus seem to stress the ambiguity of Psamathe, as we have seen above.

${ }^{43}$ See PARKES (n. 35) xvii-xx for the epic technique and the motif of delay in Statius' Thebaid. The abandoned children might also recall the myth of Oedipus. See VESSEY (n. 4) 103-105 and MCNELIS (n. 7) 41, but see DOMINIK (n. 5) 66, n. 96.

${ }_{44}$ One of the children was called Thoas.

${ }^{45}$ See for the death wish of Hypsipyle 5.627-635.

${ }^{46}$ See for the question of Hypsipyle's guilt SOERINK (n. 25) 501f. and 620-628. 
Hypsipyle's words echo Adrastus' narrative yet another time when she cries out in despair over the child's death: heu ubi siderei uultus? (5. 612) 'alas, where is your starry face?' The use of the adjective sidereus describing a person's beauty ${ }^{47}$ has only two attestations in the Thebaid: this line and the phrase sidereum Latonae ... nepotem (1.577) 'the starry grandson of Latona', referring to Linus. ${ }^{48}$

The most explicit linking of both children's death is the ekphrasis of the tapestry on Opheltes' bier on which the story of Linus is depicted - a self-conscious miniature version of Statius'/Adrastus' own narrative in book 1.

medio Linus intertextus acantho

letiferique canes: opus admirabile semper

oderat atque oculos flectebat ab omine mater.

in the middle of the acanthus Linus is woven and the death-bringing dogs: the mother always hated this admirable work and used to avert her eyes from this omen.

The tapestry was present in the family ${ }^{49}$ for some time (stressed by semper and the imperfect tense of flectabat) as an ominous possession, just like the story of Linus has been an ominous sign for readers of the Thebaid, foreshadowing the death of Opheltes. The narratives of the two boys are almost literally interwoven and the word intertextus can therefore be seen as a sign for this intratextuality. ${ }^{50}$ This is immediately demonstrated by the phrase letiferique canes, connecting these wild dogs to the $\mathrm{Ne}$ mean snake, who is called letifer anguis by Hypsipyle in 5.628 and by Amphiaraus in $5.737 .^{51}$

\subsection{Divine wrath in Argos and Lemnos}

Besides a similar context, both embedded narratives share common motifs, of which the anger and the unjust behaviour of the gods seem to be the most important. Hypsipyle is at first hesitant to reveal the past to the Argives. She speaks of a nefas (5. 32) and a 'cold Fury' (frigida .../ Eumenis 5. 32-33), but does not uncover the details of the events at Lemnos. Adrastus is not satisfied and admonishes her to clarify what she means with the nefas she mentioned.

aduertere animos, maiorque et honora uideri

parque operi tanto; cunctis tunc noscere casus

ortus amor, pater ante alios hortatur Adrastus:

${ }^{47}$ OLD s.v. 2 'having a star-like brightness or beauty'.

${ }^{48}$ VESSEY (n. 4) 104. See for the motif of the deceased's former beauty SOERINK (n. 25) 613f., who rather sees Silv. 2. 1. 41-42 as 'the closest Statian parallel'.

${ }^{49}$ Does mater signify his biological mother Eurydice or his foster-parent Hypsipyle? The latter emphasises her maternal feelings for Opheltes in 5. 617618 and 632-633, which is confirmed by Eurydice's words illa tibi genetrix (6. 166). See SOERINK (n. 25) 617-618.

${ }^{50}$ For these lines as intertextual self-reference see e.g. SOERINK (n. 25) 39. For intertextus as a marker of intertextuality see e.g. MCNELIS (n.7) 38-39, suggesting an allusion to Callimachus.

${ }^{51}$ SOERINK (n. 25) 40. 
'immo age, dum primi longe edimus agmina uulgi

(...)

pande nefas ...'

They pay attention; she seemed greater and honourable and fit for such a great task; then in all a desire arose to learn about her misfortunes. Before everyone else father Adrastus urges her: 'Come on, while we bring in long array the troops of our first soldiery (...) unfold the crime.'

This introduction to Hypsipyle's narrative mirrors Adrastus' own words in book 1 when he starts his aetiological narrative to Tydeus and Polynices: animos aduertite, pandam (1.561) 'pay attention, I will unfold.' The narrative roles are now inversed: the narrator of a story about the origins of a religious festival now asks Hypsipyle to present her narrative about nefas. ${ }^{52}$

In Hypsipyle's narrative, Venus plays the role of the revengeful goddess, angered because she is not worshipped on Lemnos, an island sacred to her husband Vulcan.

dis uisum turbare domos, nec pectora culpa

nostra uacant: nullos Veneri sacrauimus ignes,

nulla deae sedes; mouet et caelestia quondam

corda dolor lentoque inrepunt agmine Poenae.

It is a pleasure to the gods to upset houses, but our hearts were not free from guilt: we consecrated no fires to Venus; there was no temple for the goddess. Sometimes grief even sets divine hearts in motion and the goddesses of vengeance creep in with a slow march.

The Lemnians may be blamed for their negligence of Venus, but the goddess is taken over by emotions like grief and vengeance as the Poenae slowly march in. These personifications of vengeance are often associated with the Furies, who assist Venus in exacting her retribution in Lemnos. ${ }^{53}$ Perhaps the choice of the name Poenae for the Furies is a hint at the name of Apollo's monster, which is called Poine ('Goddess of Vengeance') in other sources. ${ }^{54}$ Together with these infernal deities, Venus inspires the Lemnian women to kill all men on the island. Exactly at this point in the queen's narrative, parallels with the tale in book 1 start to appear.

erant certe media quae noctis in umbra

diuam alios ignes maioraque tela gerentem

Tartareas inter thalamis uolitasse Sorores

uulgarent, utque implicitis arcana domorum

${ }^{52}$ The combination noscere casus (5.41) is an intertextual echo to the frame narrative on Antaeus in Luc. 4. 591: noscere causas, 4. 591. This aetiological tale is modelled on the frame narrative of Hercules and Cacus in Verg. A. 8. 185-267, an important intertext for the narrative of Adrastus as well.

${ }^{53}$ See TLL 10.1.2505.1ff s.v.

${ }^{54}$ See LSJ s.v. II and n. 28. VeSSEY (n. 4) 104 suggests a similar ironic pun in 1. 578, where Psamathe is said to have handed over her child to the shepherd poenae metuens. 
anguibus et saeua formidine nupta replesset

limina nec fidi populum miserata mariti.

Certainly there were women who told that in the shadow of midnight the goddess carrying other fires and larger weapons - the Tartarean Sisters flew around in bedrooms and how she had filled secret places in our homes with twined snakes and our nuptial thresholds with fierce terror, pitying not even the people of her faithful husband.

This scene reminds the reader of Apollo's monster, which was created in the Furies' bedrooms (conceptum Eumenidum thalamis, 1. 598), roaming through Argive bedchambers (thalamis, 1. 602). Serpents, as mentioned in this passage, are often connected with the Furies. But they recall at the same time Apollo's monster, which has an anguis on her head: ferrugineam frontem discriminat anguis (1.600) 'a snake separates her iron-red forehead'.

There is great irony in the punishment that Venus has in mind for the Lemnians, as her own husband Hephaestus is loyal to her (fidi ... mariti, 5. 71), while she herself is unfaithful to him. ${ }^{55}$ Such irony can be detected in the narrative of book 1 as well, where Apollo punishes Argos for the death of his child by letting the monster kill other infants.

\subsection{The Nemean snake and the Python}

History seems to repeat itself once again when the Nemean snake, which is described in much the same way as the Python in book 1, appears on stage. ${ }^{56}$ Both serpents are earth-born (terrigenam Pythona $1.563 \sim$ terrigena ... serpens 1.506 ), both have three-forked tongues (ore trisulso 1. $565 \sim$ ter lingua 5. 509), and both are venomous (nigro ueneno $1.566 \sim$ tumidi ... ueneni 5. 508). These words may be simply part of the common description of snakes, but other allusions affirm the connection between the two snakes.

nunc ille dei circumdare templa

orbe uago labens, miserae nunc robora siluae

atterit et uastas tenuat complexibus ornos.

Now gliding in a wavy circle he surrounds the god's shrine, now he grinds the oaks of the miserable forest and thins down huge ash trees with his embraces.

This moving around of the Nemean snake recalls that of the Python in book 1: 8. 267-366.

${ }^{55} \mathrm{Cf}$. the well-known embedded narrative on the love affair between Aphrodite and Ares in $\mathrm{Od}$.

${ }^{56}$ See for these correspondences especially VESSEY (n. 4) 104-105 and SOERINK (n. 25) 40-44. An important model for both snake narratives is the Theban serpent of Ov. Met. 3. 28-49, on which see VESSEY (n. 4) 187 and SOERINK (n. 25) 109-110. 


\author{
septem orbibus atris \\ amplexum Delphos squamisque annosa terentem \\ robora
}

having embraced Delphi with his seven black circles and grinding ancient oaks with his scales

The verbal parallels between the two serpents are clear: orbe $\sim$ orbibus; robora $\sim$ robora; atterit $\sim$ terentem; complexibus $\sim$ amplexum. ${ }^{57}$

When Hypsipyle and the Argives have discovered that the snake killed Opheltes, the soldiers kill the beast in a way that not only recalls Apollo's defeat of the Python, but also the Argives mutilating the corpse of Apollo's monster. Hippomedon is said to have thrown huge rocks at the Nemean serpent (molares, 5. 561), which recalls the rocks with which the Argives trample the monster's face asprosque molares (1. 622). ${ }^{58}$

The connection with the Python is made explicit in a simile, in which the narrator compares the corpse of the Nemean serpent with the zodiac sign Anguis and the Delian snake respectively.
quantus ab Arctois discriminat aethera plaustris
Anguis et usque Notos alienumque exit in orbem; quantus et ille sacri spiris intorta mouebat cornua Parnasi, donec tibi, Delie, fixus uexit harundineam centeno uulnere siluam.

Large as the Snake that divides heaven from the Arctic Wains and ends all the way to the South Winds and a foreign hemisphere; large also as he who moved the horns of Parnassus, twined between his coils, until you, Delian, pierced him and he bore a forest of arrows with one hundred wounds.

The second part of the simile 'plainly recalls and develops' the description of the Python by Adrastus. ${ }^{59}$ The 'hundred wounds' especially recall the narrative of book 1 , conflating two phrases:

perculit, absumptis numerosa in uulnera telis,

Cirrhaeique dedit centum per iugera campi

[Apollo] cast [the snake] down, using up his arrows for numerous wounds and stretches it out over a hundred acres of Cirrha's plain

Statius seems to 'correct' his own (or rather Adrastus') narrative by downsizing the number of arrows Apollo needed for killing the Python from 'numerous' to 'a hun-

${ }^{57}$ See CAViglia (n. 33) 564-565.

${ }^{58} \mathrm{Cf}$. also the molares that are thrown at the corpse of Cacus in Verg. A. 8. 250, already noted by Lactantius. HEUVEL (n. 15) 622f., however, follows Barth's suggestions that the molares are the monster's teeth.

${ }^{59}$ Hutchinson, G. O.: Latin Literature from Seneca to Juvenal. Oxford, 1993, 123, n. 24 and SOERINK (n. 25) 531-533. 
dred'. ${ }^{60}$ Moreover, Apollo's apostrophe Delie refers of course to the location where the god slaughtered the Python, but also echoes the use of this epithet for Apollo in Adrastus' narrative (Delia ... furta, 1. 573-574; Delius, 1. 628).

The first part of the simile, comparing the Nemean snake with the zodiac sign Anguis, ${ }^{61}$ might contain an allusion to Apollo's monster Poine, whose forehead is divided by a snake: ferrugineam frontem discriminat anguis (1. 600). These allusions again draw attention to the fact that Apollo is both a slayer and a creator of monsters.

After killing the Nemean snake, the Argives organise games in honour of Opheltes, thereby following the footsteps of Apollo, who is claimed to have initiated the Pythian games to commemorate his killing of the Python. Adrastus is silent on this matter, but the narrator states at the beginning of book 6 that the new Nemean games are to be placed on a continuum with Greek festivals that were founded earlier, starting with the Olympian ones and followed by the Pythian ones:

proxima uipereo celebratur libera nexu

Phocis, Apollineae bellum puerile pharetrae

Next Phocis is celebrated, liberated from the serpentine entwining, the boyish war of the Apollonian quiver

\section{CONCLUDING REMARKS}

History (and narrative) repeats itself in the Thebaid. This repetition is marked on a verbal level by intratextual allusions. This paper is a case study of Statian intratextuality and the effects it has on the interpretation of single episodes and on the connection between episodes. We have also seen that these echoes can highlight motifs that play an important role in the Thebaid as a whole. Verbal repetition brings about a connection between characters, events, motifs and episodes, sometimes creating unity, sometimes rather discontinuity or ambiguity. There remains much fruitful work to be done in the field of Statian (and Flavian) intratextual allusiveness.

Pieter J. van den Broek

University of Amsterdam

Amsterdam Centre for Ancient Studies and Archaeology

Turfdraagsterpad 9

1012 XT Amsterdam

The Netherlands

p.j.vandenbroek@uva.nl

${ }^{60}$ SOERINK (n. 25) 533f. suggests that Statius 'playfully improves on Ovid's Apollo, who needed not a hundred, but a thousand arrows to kill Python'.

${ }^{61}$ It is not entirely clear which sign Statius actually means, as the ambiguous Anguis can refer to Dragon, Serpent or Snake. See for a clear overview of the discussion SOERINK (n. 25) 529-530.

${ }^{62} \mathrm{H}$. W. ForTGens (P. Papinii Statii de Opheltis funere carmen epicum, Thebaidos liber VI 1295, versione Batava commentarioque exegetico instructum. Zutphen 1934, 9f.) quotes in this context a possible allusion to Adrastus' hymn to Apollo at the end of book 1, where Apollo's quiver is also mentioned in connection with the slaughtering of the Python: te [sc. Apollo] uiridis Python Thebanaque mater [sc. Niobe] ouantem / horruit in pharetris (1.711-712). 
